\title{
The role of antifungals in the management of patients with severe asthma
}

\author{
W. Garth Rapeport ${ }^{{ }^{*}}$ (D) Kazuhiro Ito ${ }^{1,2}$ and David W. Denning ${ }^{3}$
}

\begin{abstract}
In patients with asthma, the inhalation of elevated amounts of fungal spores and hyphae may precipitate the onset of asthma or worsen control to the extent of being life-threatening. Sensitisation to fungi, especially Aspergillus fumigatus, is found in $15 \%$ to $48 \%$ of asthmatics in secondary care and is linked to worse asthma control, hospitalisation, bronchiectasis and fixed airflow obstruction, irrespective of whether allergic bronchopulmonary aspergillosis (ABPA) is diagnosed. ABPA represents a florid response to the presence of Aspergillus spp. but up to $70 \%$ of patients with severe asthma exhibit sensitisation to different fungi without meeting the diagnostic criteria for ABPA. The presence of persistent endobronchial colonisation with fungi, especially A. fumigatus, is linked to significantly higher rates of radiological abnormalities, lower post-bronchodilator FEV1 and significantly less reversibility to short acting bronchodilators. The therapeutic benefit for antifungal intervention in severe asthma is based on the assumption that reductions in airway fungal burden may result in improvements in asthma control, lung function and symptoms (especially cough). This contention is supported by several prospective studies which demonstrate the effectiveness of antifungals for the treatment of ABPA. Significantly, these studies confirm lower toxicity of treatment with azoles versus high dose oral corticosteroid dosing regimens for ABPA. Here we review recent evidence for the role of fungi in the progression of severe asthma and provide recommendations for the use of antifungal agents in patients with severe asthma, airways fungal infection (mycosis) and fungal colonisation. Documenting fungal airways colonisation and sensitisation in those with severe asthma opens up alternative therapy options of antifungal therapy, which may be particularly valuable in low resource settings.
\end{abstract}

Keywords: Severe asthma, ABPA, Antifungals, Biologics, Itraconazole, Voriconazole, Aspergillus

\section{Background}

Severe asthma is a complex heterogenous disease which has been described as "the requirement for high dose inhaled corticosteroids plus a second controller and/ or systemic corticosteroids to prevent it from becoming "uncontrolled" or which remains "uncontrolled" despite this therapy" [1].

The natural history of severe asthma is characterised by a long-term decline in lung function, irreversible airways remodelling and increased risk for life-threatening

${ }^{*}$ Correspondence: w.rapeport@imperial.ac.uk

${ }^{1}$ Airways Disease, National Heart and Lung Institute, Imperial College, London SW3 6LY, UK

Full list of author information is available at the end of the article exacerbations. In recent years, significant effort has been directed towards the identification of specific phenotypes which are based on analysis of clinical and biomarker characteristics. Asthma phenotypes may be further subdivided into a small number of endotypes representing distinct disease entities which may benefit from personalised treatment [2]. Fungi are known to play a significant role in allergic airways disease which has been exemplified by allergic bronchopulmonary aspergillosis (ABPA) which is a well described but relatively uncommon endotype $[3,4]$.

Whilst ABPA represents a florid response to the presence of Aspergillus spp., up to $70 \%$ of patients with severe asthma exhibit sensitisation to different fungi but do not meet the diagnostic criteria for ABPA $[1,3,5]$. 
This heterogeneous population has been termed "severe asthma with fungal sensitisation" (SAFS) which is diagnosed with the use of skin prick tests (SPT) and fungal specific IgE responses (Table 1). The conventional diagnostic criteria for ABPA have been subject to revision as a growing recognition that there is broad overlap with a population with fungal sensitisation, airways obstruction and lung tissue damage $[3,4,6]$. In this paper, we provide recommendations on the use of antifungal agents in the patient with SAFS. Fungal nomenclature has changed radically in the last 2 decades and much of the older literature on fungal sensitisation, and indeed many of the currently approved IgE assays and skin test reagents use names that are now obsolete. Additional file 1: Table S1 shows some of the most important allergic fungi and the genera they now belong to and the summary names we use in this paper (see Additional file 1: Table S1).

\section{Main text}

\section{Fungal sensitisation, severe asthma and ABPA}

Fungal sensitisation to thermotolerant species such as Aspergillus has been linked with uncontrolled asthma but the natural history in this population has not been documented in longitudinal studies [3, 5]. A range of radiological abnormalities have been observed including higher than expected rates of bronchiectasis in patients with sensitisation to Aspergillus attending severe asthma clinics [7-9]. A recent large cross-sectional study in asthmatics with Aspergillus sensitisation documented a range of radiological abnormalities specifically associated with sensitisation to Aspergillus but not to environmental fungi such as Alternaria and Cladosporium suggesting a possible causal relationship [7].

ABPA is described as a progressive disorder with recurrent, infrequent acute episodes that cause successive bronchial damage. Although patients with ABPA are subject to disease progression with long-term remissions, the natural history has not been well described and not all patients progress in a longitudinal fashion $[3,5$, 6]. Patients with ABPA usually have moderate or severe asthma, but not all. A number studies have highlighted the role for antifungals for the treatment of ABPA [1013] (Table 2).

Approximately $5 \%$ of the general population, up to $42 \%$ of atopic patients, and $70 \%$ of patients with severe asthma are sensitised to one or more of approximately 80 different fungi $[3,5]$. The prevalence of fungal sensitisation displays wide geographical variation. Exposure to fungi, and/or dampness at home with the presumption of fungal growth in the home or work, can precipitate the development of asthma. This is well documented in infants, children and teenagers in multiple studies [14-16]. Furthermore, in asthmatic children and adults, significant fungal exposure exacerbates asthma, on occasion precipitating hospital admission [16-18]. Alternaria sensitisation in childhood in linked to persistent asthma in adulthood [19].

Relatively few severe asthma population studies have been published. A recent study in Sweden of 1006 adults [20] reported $27-32 \%$ with sensitisation to moulds with an elevated serum IgE among those with severe asthma. The severe asthma prevalence and fungal sensitisation rates in this study were broadly consistent with data reported in other population-based studies in Denmark, Belgium and Israel [21-25], although lower than in secondary care cohorts the UK $[26,27]$ and Singapore (6680\%) [28].

The number of adults with severe fungal asthma (encompassing ABPA and SAFS) is large. A global estimate of ABPA based on adult asthma prevalence was 4.7 million [29]. A recent literature review from Africa indicates a $6 \%$ asthma prevalence and a pooled estimate of fungal sensitisation of $23.3 \%$, so about 4 million people there with SAFS and/or ABPA [30]. In India, where ABPA is particularly common, the best estimate of ABPA prevalence was 1.38 million with an additional 1 million with SAFS [31]. In Brazil, an estimated 390,500 adults have ABPA and nearly 600,000 have SAFS [32], probably with some overlap in cases. A report from the Global Action Fund for Fungal Infections (GAFFI) related to Latin America put the total number of fungal asthma cases about $\sim 1.58$ million or 254 per 100,000 [33].

\section{Persistent lung colonisation with Aspergillus is linked to severe asthma}

Investigators have detected high rates of positive sputum culture samples for A. fumigatus in SAFS and ABPA populations, with greater than $80 \%$ of subjects having at least one positive sputum result at some point $[7,8,26,34$, 35]. Persistent Aspergillus colonisation of the airways has been linked to adverse clinical outcomes which include higher rates of radiological abnormalities, lower postbronchodilator FEV1, and significantly less reversibility to short acting bronchodilators in patients with a positive sputum fungal culture [8,34-37]. A heavy burden of fungal colonisation may occur in the absence of IgE sensitisation, a condition which has been called fungal bronchitis. Fungal bronchitis may present with chronic productive cough, loss of asthma control and a decline in lung function and is responsive to treatment with oral azoles $[4,38]$.

\section{Diagnosis of fungal allergy in the patient with asthma}

The term "Severe Asthma with Fungal Sensitisation" (SAFS) was introduced by Denning et al. in 2006, to describe those patients who have persistent severe 


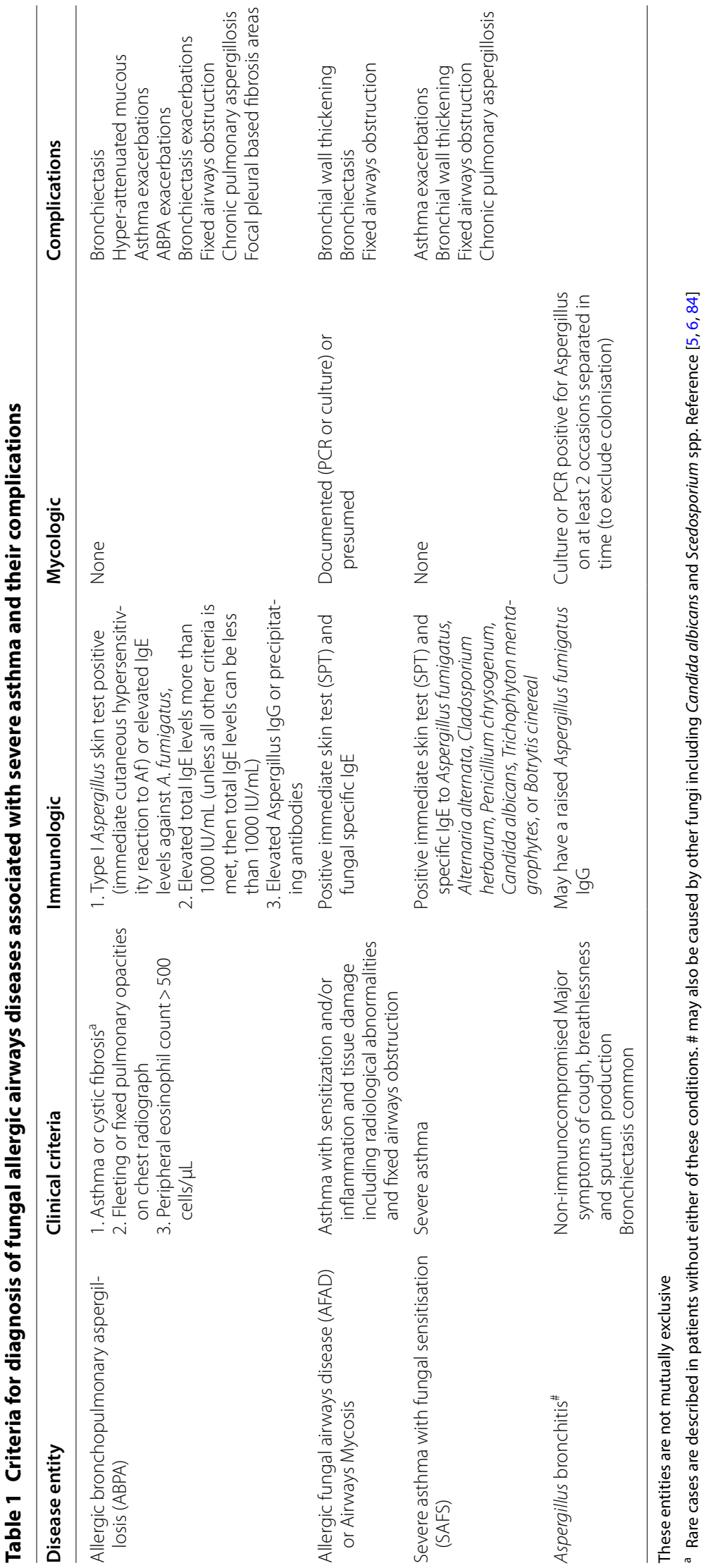


Table 2 Overview of antifungal clinical studies (Chronological order)

\begin{tabular}{|c|c|c|c|c|c|c|c|c|c|}
\hline Antifungal & Dose & Route & target & Fungi & $\mathbf{n}$ & Design & Duration & $\begin{array}{l}\text { benefits/ } \\
\text { outcome }\end{array}$ & Refs. \\
\hline Ketoconazole & $400 \mathrm{mg}$, qd & oral & $\begin{array}{l}\text { ABPA, Asper- } \\
\text { giloma }\end{array}$ & S & 10 & DB & $12 \mathrm{M}$ & $\begin{array}{l}\text { Af-lgG, symptom } \\
\text { score }(\downarrow)\end{array}$ & Shale [85] \\
\hline Itraconazole & 50-400 mg, qd & oral & $\begin{array}{l}\text { Aspergillosis } \\
\text { Aspergilloma }\end{array}$ & S & 137 & Open & 11-780D & $\begin{array}{l}5 \text { ABPA patients: } \\
\text { Symptom } \\
(4 / 5 \downarrow) \text { Fungus } \\
(3 / 4 \downarrow) \\
\text { cure/ } \\
\text { improved:60\% } \\
\text { in IA, 66\% } \\
\text { in chronic } \\
\text { necrotising } \\
\text { pulmonary } \\
\text { aspergillosis }\end{array}$ & De Beule [86] \\
\hline $\begin{array}{l}\text { Inhaled Nata- } \\
\text { mycin }\end{array}$ & $5 \mathrm{mg}$, bid & inhaled & ABPA & S & 25 & $\mathrm{DB}$ & $50 \mathrm{~W}$ & $\begin{array}{l}17 \text { patient (9 } \\
\text { natamycin, } \\
8 \text { placebo) } \\
\text { completed } \\
\text { No evidence } \\
\text { that natamy- } \\
\text { cin conferred } \\
\text { benefit on } \\
\text { ABPA }\end{array}$ & Currie [87] \\
\hline Itraconazole & $200 \mathrm{mg}$, bid & oral & $\begin{array}{l}\text { ABPA (CF, } \\
\text { asthma) }\end{array}$ & SC & 6 & Open & $\begin{array}{l}\text { 1-6 M (3.9 M } \\
\text { mean) }\end{array}$ & $\begin{array}{l}\text { Symptom, tlgE, } \\
\text { steroid use } \\
(\downarrow), \text { Af-lgG } \\
(\rightarrow) \text {, sputum } \\
\text { culture nega- } \\
\text { tive in } 2 / 3\end{array}$ & Denning [88] \\
\hline Itraconazole & $200 \mathrm{mg} q \mathrm{~d}$ & oral & ABPA & S & 12 & Open & $\geq 6 \mathrm{M}$ & $\begin{array}{l}\text { 11/12 improve- } \\
\text { ment, blood } \\
\text { eosinophil, } \\
\text { tlgE }(\downarrow), A f \\
\text { precipitins -ve } \\
(7 / 12)\end{array}$ & Germaud [89] \\
\hline Fluconazole & $100 \mathrm{mg} q d$ & oral & $\begin{array}{l}\text { Asthma with } \\
\text { dermatophy- } \\
\text { tosis }\end{array}$ & C & 11 & $\mathrm{DB}$ & $5 M+36 M$ & $\begin{array}{l}\text { bronchial } \\
\text { sensitivity to } \\
\text { Trichophyton, } \\
\text { oral steroid } \\
\text { use and } \\
\text { symptom }(\downarrow) \\
\text { PEF }(\uparrow)\end{array}$ & Ward [68] \\
\hline Itraconazole & $200 \mathrm{mg}$ qd & oral & ABPA & S & 14 & Open & $12 \mathrm{M}$ & $\begin{array}{l}\text { Lung function } \\
(\uparrow) \text {, blood eso- } \\
\text { pinophilia, tlgE } \\
\text { and steroid } \\
\text { use }(\downarrow) \text {, Af-lgE } \\
(\rightarrow) \text {, }\end{array}$ & Salez [90] \\
\hline Itraconazole & $200 \mathrm{mg}$ bid & oral & ABPA & $S$ & 55 & $\mathrm{DB}$ & $16 \mathrm{~W}$ & $\begin{array}{l}\text { Overall improve- } \\
\text { ment (19\% } \\
\text { Placebo, } 46 \% \\
\text { ITC), \%change } \\
\text { on tlgE - } 60 \% \\
\text { ITC vs. -44\% } \\
\text { PLB }\end{array}$ & Stevens [58] \\
\hline
\end{tabular}


Table 2 (continued)

\begin{tabular}{|c|c|c|c|c|c|c|c|c|c|}
\hline Antifungal & Dose & Route & target & Fungi & $\mathbf{n}$ & Design & Duration & $\begin{array}{l}\text { benefits/ } \\
\text { outcome }\end{array}$ & Refs. \\
\hline Itraconazole & 400 mg qd & oral & ABPA & $\mathrm{S}$ & 29 & $\mathrm{DB}$ & $16 W$ & $\begin{array}{l}\text { Sputum eosino- } \\
\text { phil, ECP and } \\
\text { serum tlgE/ } \\
\text { Af-lgG against } \\
\text { A. fumigatus } \\
(\downarrow), \text { Exacerba- } \\
\text { tion requiring } \\
\text { oral steroids } \\
(\downarrow), \% \text { change } \\
\text { on tlgE -20\% } \\
\text { ITC vs. }+1 \% \\
\text { PLB }\end{array}$ & Wark [59] \\
\hline $\begin{array}{l}\text { Itraconazole } \\
\text { Fluconazole }\end{array}$ & $\begin{array}{l}200 \mathrm{mg} \text { qd } \\
150 \mathrm{mg} \text { qd }\end{array}$ & oral & ABPA & S & 44 & RS & $6 \mathrm{M}$ & $\begin{array}{l}\text { ITC > FLU: Bet- } \\
\text { ter control } \\
\text { of asthma } \\
\text { symptom, less } \\
\text { requirement } \\
\text { of reliever/ } \\
\text { steroid, lesser } \\
\text { exacerbation, } \\
\text { vs. non-treat- } \\
\text { ment }\end{array}$ & Rai [91] \\
\hline Itraconazole & 200 mg bid & oral & SAFS & $\mathrm{S}$ & 58 & $\mathrm{DB}$ & $32 W$ & $\begin{array}{l}\text { AQLQ, Rhinitis } \\
\text { score, PFT, tlgE } \\
\text { (improved } \\
\text { vs. Placebo). } \\
60 \% \text { large } \\
\text { improvement. } \\
\text { \%change on } \\
\text { tlgE -27\% ITC } \\
\text { vs. + 12\% PLB }\end{array}$ & Denning [61] \\
\hline Itraconazole & $100-450 \mathrm{mg}$ qd & oral & $\begin{array}{l}\text { ABPA } \\
\text { SAFS }\end{array}$ & S & 33 & RS & $>6 \mathrm{M}$ & $\begin{array}{l}\text { Lung function } \\
\text { ( } \uparrow), \text { tlgE, Af- } \\
\text { RAST, eosino- } \\
\text { phil, steroid } \\
\text { use }(\downarrow)\end{array}$ & Pasqualotto [92] \\
\hline $\begin{array}{l}\text { Voriconazole } \\
\text { Posaconazole }\end{array}$ & $\begin{array}{l}300-600 \mathrm{mg} \text { qd } \\
800 \mathrm{mg} \text { qd }\end{array}$ & oral & $\begin{array}{l}\text { ABPA, SAFS } \\
\text { (Iraconazole- } \\
\text { failed) }\end{array}$ & $S$ & 25 & Open & $\geq 6 M$ & $\begin{array}{l}\text { Clinical response } \\
\text { VOR (70\% in), } \\
\text { POS (78\%) } \\
\text { after } 3 \mathrm{M} \text { treat- } \\
\text { ment } \\
\text { tlgE, RAST-Af }(\downarrow) \\
\text { after } \geq 9 \mathrm{M} \\
\text { treatment }\end{array}$ & Chishimba [13] \\
\hline $\begin{array}{l}\text { Voriconazole } \\
\text { (EVITA3) }\end{array}$ & 200 mg bid & oral & $\begin{array}{l}\text { Af associated } \\
\text { asthma }\end{array}$ & $S$ & 56 & $\mathrm{DB}$ & $3 M$ & $\begin{array}{l}\text { no difference on } \\
\text { severe exacer- } \\
\text { bation, QOL, } \\
\text { lung function, } \\
\text { t or Af-lgE/lgG, } \\
\text { blood/sputum } \\
\text { eosinophil vs. } \\
\text { placebo }\end{array}$ & Agbetile [62] \\
\hline Amphotericin B & 10 mg bid & nebulised & $\begin{array}{l}\text { ABPA, SAFS } \\
\text { (Itraconazole/ } \\
\text { voriconazole } \\
\text { failed) }\end{array}$ & $S$ & 21 & Open & $\begin{array}{l}\text { 30D (median) } \\
0-1825 \mathrm{D}\end{array}$ & $\begin{array}{l}\text { 14\% }(3 / 21) \text { Clini- } \\
\text { cal benefit } \\
33 \%(7 / 21), \\
\text { failed initial } \\
\text { dose due to } \\
\text { Bronchospasm } \\
52 \%(11 / 21), \\
\text { discontinued } \\
\text { within } 12 \mathrm{M}\end{array}$ & Chishimba [11] \\
\hline
\end{tabular}


Table 2 (continued)

\begin{tabular}{|c|c|c|c|c|c|c|c|c|c|}
\hline Antifungal & Dose & Route & target & Fungi & $\mathbf{n}$ & Design & Duration & $\begin{array}{l}\text { benefits/ } \\
\text { outcome }\end{array}$ & Refs. \\
\hline Amphotericin B & $\begin{array}{l}10 \text { mg bid thrice } \\
\text { a week }\end{array}$ & nebulised & ABPA & $\mathrm{S}$ & 21 & DB & $4 \mathrm{M}$ & $\begin{array}{l}\text { Frequency of } \\
\text { exacerba- } \\
\text { tion ( } \downarrow \text { vs. } \\
\text { nebulized } \\
\text { budesonide), } \\
3 \text { patients, } \\
\text { bronchospasm } \\
\text { after nebuliza- } \\
\text { tion of AMB }\end{array}$ & Ram [12] \\
\hline Itraconazole & 200 mg bid & oral & $\begin{array}{l}\text { ABPA (acute } \\
\text { stage) }\end{array}$ & S & 131 & DB & $4 \mathrm{M}$ & $\begin{array}{l}\text { ITC was effec- } \\
\text { tive, but over- } \\
\text { all efficacy: } \\
\text { ITC < pred- } \\
\text { nisolone, } \\
\text { side effects } \\
\text { ITC < predniso- } \\
\text { lone } \\
\text { The time to } \\
\text { the first } \\
\text { exacerbation: } \\
\text { ITC= predni- } \\
\text { solone } \\
\% \text { change on } \\
\text { tlgE -66\% ITC } \\
\text { vs. } 67 \% \text { PDS }\end{array}$ & Agarwal [10] \\
\hline Voriconazole & 200 mg bid & oral & $\begin{array}{l}\text { ABPA (acute } \\
\text { stage) }\end{array}$ & $S$ & 50 & $\begin{array}{l}\text { unblinded, } \\
\text { ran- } \\
\text { domised }\end{array}$ & $4 \mathrm{M}$ & $\begin{array}{l}\text { VRC: Exacerba- } \\
\text { tion, IgE, } \\
\text { SGRQ }(\downarrow) \text {, Lung } \\
\text { function }(\uparrow) \\
\text { But, VRC appears } \\
\text { to be as } \\
\text { effective as } \\
\text { prednisolone }\end{array}$ & Agarwal [93] \\
\hline Amphotericin B & 10 mg bid & nebulised & $\begin{array}{l}\text { Pulmonary } \\
\text { Aspergillosis }\end{array}$ & S & 177 & RS & $4 \mathrm{M}$ to $6 \mathrm{Y}$ & $\begin{array}{l}\text { Poorly tolerated } \\
\text { (66\% only) due } \\
\text { to increased } \\
\text { breathlessness } \\
\text { Some patients } \\
\text { showed t/Af } \\
\text { lgE, Af-lgG( } \downarrow)\end{array}$ & Otu [60] \\
\hline
\end{tabular}

ABPA, Allergic Bronchopulmonary Aspergillosis; Af, Aspergillus fumigatus; AMB, Amphotericin B; bid, bis in die (twice daily); $C$, colonised (culture; PCR or any format of fungal detection); D, day; DB, double blind; ITC, itraconazole; M, month; PDS, prednisolone; POS, posaconazole; PLB, placebo; qd, quaque die (once daily); RS, retrospective; S, sensitised (blood lgE or skin); SAFS, Severe Asthma with Fungal Sensitisation; tlgE, total IgE; VOR, voriconazole; W, week; Y, year

asthma (despite standard treatment) and evidence of fungal sensitisation, as defined by positive SPT, or fungus or fungal antigen-specific IgE, and do not meet the criteria for ABPA [3]. The diagnosis of ABPA can be reliably ascertained where the disease is florid but there may be uncertainty with early disease presentation particularly in the absence of bronchiectasis (Table 1). No single test has both good sensitivity and specificity for the diagnosis of ABPA-a definitive diagnosis depends on 8 parameters which include the following: asthma or CF; immediate Aspergillus skin prick test positivity, IgE levels $>1000 \mathrm{IU} / \mathrm{mL}$, positive A. fumigatus specific IgE (no value specified or studied), Aspergillus precipitins (or IgG) detectable, eosinophil count $>1,000$ cells/
uL, transient pulmonary radiographic opacities, (central) bronchiectasis and high attenuation mucus [4-6]. ABPA is relatively unusual-about $10 \%$ of people with asthma associated with IgE sensitisation to Aspergillus fulfil all the standard criteria for ABPA [3-5, 39]. There is limited evidence that total IgE is linked to disease severity, but it continues to be widely used as a primary marker of differentiation between ABPA and the diagnosis of fungal sensitisation [40]. This has led to the proposition that a more liberal definition for allergic fungal airways disease should be adopted which removes the requirement to differentiate ABPA for SAFS using total IgE levels as the main discriminator $[39,40]$. 
A positive SPT has value as a screening test for sensitisation, but it is recognised that specific $\operatorname{IgE}$ to $A$. fumigatus is the most useful biomarker for the diagnosis of fungal sensitisation $[3,5,39]$. A proposed positive cutoff for A. fumigatus-specific IgE (0.35 kUA/L) is two to three times the level of $A$. fumigatus-specific IgE in asthmatics who are already demonstrating positive results on Aspergillus skin test [6]. It is important to note that there may be discrepancies between SPT and fungal specific IgE responses which may be explained by batch to batch variations in the production of fungal extracts. Assays for A. fumigatus specific IgE are commercially available and might minimize the cross-reaction among different fungal species, which tend to occur when crude extracts of allergen are used. This has led to the recommendation that SPT and fungal specific IgE levels should both be required to confirm the diagnosis of fungal sensitisation, but this ignores the problem of extract variability [40].

Fungal specific IgE sensitisation to $A$. fumigatus has been reported in a population of asthmatics with fixed airflow obstruction and radiological abnormalities [7] which suggests that the sensitisation to thermotolerant filamentous fungi is the major risk factor for the development for lung damage in asthma irrespective of whether the criteria for ABPA are present $[39,40]$. To address this population, the concept of allergic fungal airways disease (AFAD) has been proposed where fungal sensitisation occurs in addition to evidence of lung tissue damage, usually documented by radiological abnormalities [3, 7 , $39,40]$. A broader term recently introduced is "airways mycosis", encompassing the upper and lower airways and emphasising the presence of fungi in the airway, driving aberrant immunological responses [41].

To increase diagnostic sensitivity, significant effort has gone into the search for additional markers of disease severity. Numerous allergens from the genus Aspergillus have been identified using sera from patients with ABPA [42]. Allergens may be species- or genus-specific, while others are pan-allergens that display cross-reactivity across different fungi [43]. The use of purified natural or recombinant allergens has been used to map allergen sensitisation at a molecular level and has the potential to distinguish genuine sensitisation from sensitisation to cross-reactive allergens from different fungal sources [44], including different recombinant $A$. fumigatus allergens [45]. A commercially available multiplex chip contains more than 100 allergens (ISAC) which enables rapid identification of IgE responses against a broad array of pre-selected antigens [46].

Elevated precipitating antibodies against A. fumigatus, have been reported in ABPA and asthmatics with radiological infiltrates which may reflect active disease. $A$. fumigatus-specific precipitins have also been widely used in the diagnosis of ABPA, but their positive rates in cases with ABPA ranged widely [47-49]. The optimal cut-off value of $A$. fumigatus specific IgG measured by ImmunoCAP method has recently been proposed for the diagnosis of ABPA and is not required for SAFS [50]. A recently proposed revision of the criteria for the diagnosis of ABPA using a lower IgE of $417 \mathrm{IU} / \mathrm{mL}$ (as in the original definition) has been published with an overall excellent sensitivity of $96 \%$ [51]. A lateral flow assay for Aspergillus fumigatus IgG and IgM had a 92\% sensitivity and 82-91\% specificity [52, 53]. Elevated blood eosinophil levels are found in ABPA and define one treatment-responsive phenotype of asthma but also are commonly encountered in many other disorders. In a recent study, blood eosinophilia was the only inflammatory biomarker to be related to radiological markers of lung damage in asthmatics with fungal sensitisation but is not specific [54].

A recent study using qPCR detection in lower airway samples demonstrated the presence of fungi (Candida, Penicillium, Aspergillus) in $86 \%$ of adult asthmatics. Plasma and BAL IL-4, IL-6, IL-10, IL-13 and TNF- $\alpha$ correlated with fungal presence in BAL. Elevated galactomannan in BAL was identified in a small sub-group but concordance testing for $A$. fumigatus suggests that this may reflect the presence of other fungi. The authors suggest that fungal PCR measured in BAL is a sensitive indicator for the presence of fungi in the lower respiratory tract [55]. Farrant et al. also found high level of PCR signal of $A$. fumigatus in sputum samples from SAFS and ABPA [8]. Furthermore, recent mycobiome analysis [56, 57] revealed fungal colonization in higher proportion of patients with severe asthma including $A$. fumigatus spp. complex and Candida spp. and the colonization was increased with corticosteroid treatment.

A wide range of radiological abnormalities have been reported in ABPA and SAFS [6, 7, 39, 40]. High attenuation mucus (HAM) and central bronchiectasis are recognised characteristics of ABPA [6] (Figs. 1, 2). Minor degrees of bronchiectasis, upper lobe fibrosis, tree in bud and consolidation are the most frequently reported radiological abnormalities in SAFS [7-9]. These data suggest that lung damage is a consequence of Aspergillus sensitisation and may represent a disease continuum. ABPA can be effectively treated with antifungal agents $[10,13,58$, 59] (Table 2) and the concept of the disease continuum would support intervention with antifungals as a plausible approach for the prevention of disease progression and lung damage.

\section{Antifungal treatment in patients with asthma}

The rationale for antifungal treatment for asthmatics with allergic fungal airways disease has been based on 


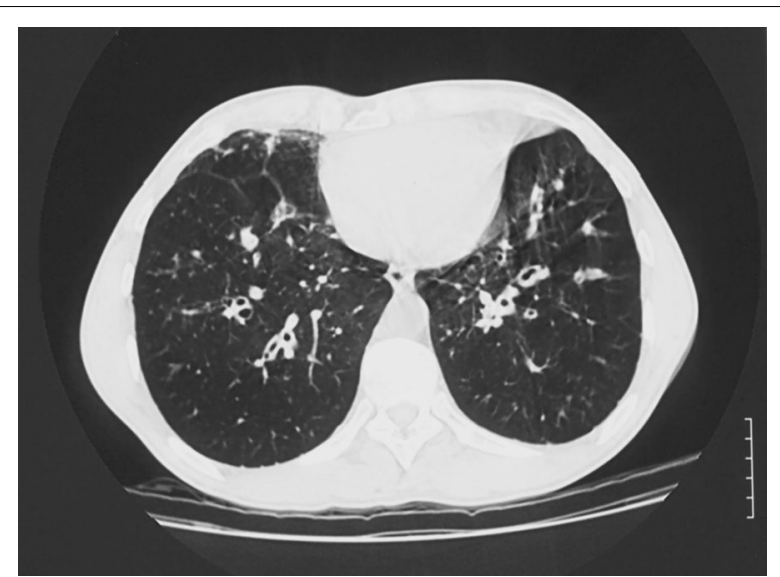

Fig. 1 Bronchiectasis complicating ABPA. Bilateral lower lobe bronchiectasis with marked bronchial wall thickening in most bronchi, but not all. Some distal air trapping and some tree in bud appearances

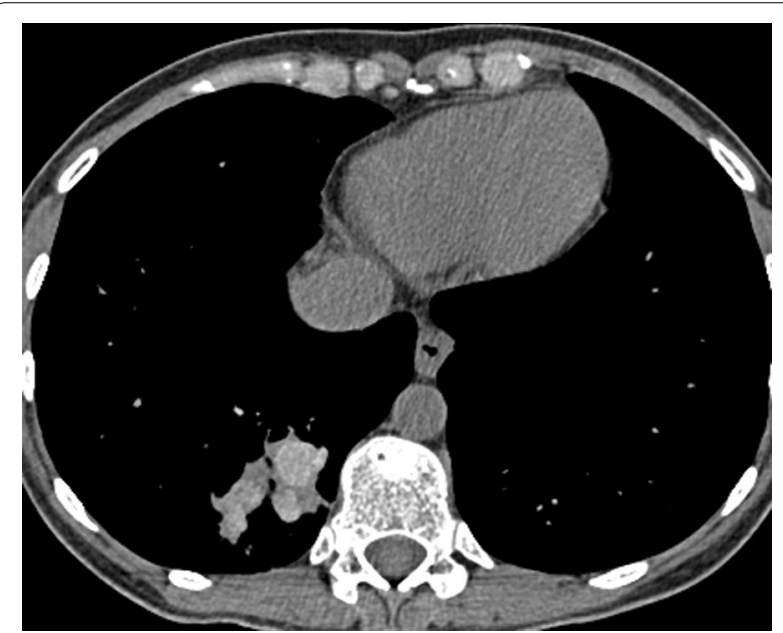

Fig. 2 Hyper-attenuated mucous obstructing distal segments of the right lower lobe in ABPA. Woman with asthma who developed ABPA after exposure to a mouldy house (new renovation that leaked). During pregnancy starting coughing black plugs up and had an episode of 'pneumonia'. CT scan shows rounded opacities posteriorly in the right lung base which are enlarged bronchi full of mucus. On the lung windows, rounded shadows are typical of mucus in bronchi, with some surrounding inflammatory change, on the bone windows (shown here), the mucus in some places appears white than others, consistent with hyper-attenuated mucous (HAM)

the adverse association of Aspergillus colonisation in the airways with asthma disease severity [7-9, 28, 34].

Relatively few prospective, controlled studies have been undertaken (Table 2) but consistent improvements in asthma control have been reported following treatment with a variety of antifungal agents. Most prospective controlled trials report the use of itraconazole in the treatment of ABPA and SAFS [10, 37, 58, 59].

In the multicentre trial of Stevens et al., $46 \%$ of patients with ABPA receiving itraconazole responded compared with $19 \%$ of those receiving placebo $(p<0.04)$ [58]. In the study of Wark et al. treatment with itraconazole resulted in normalisation of sputum eosinophilia, eosinophil cationic protein level, and a decrease in serum total IgE level and Aspergillus-specific IgG level [59]. These results suggest an anti-inflammatory benefit of itraconazole in ABPA in asthma patients which is believed to be the consequence of reduced Aspergillus antigenic stimulus.

A randomised open label study of 131 treatment-naive patients with ABPA has recently published [10]. Patients were allocated for treatment with itraconazole or prednisolone for 4 months. The primary outcomes included the composite response after 6 weeks, percent decline in IgE after treatment, and exacerbation rates. The composite response at 6 weeks was higher in the prednisolone group but the decline in IgE and exacerbation rates after 1 and 2 years of treatment were similar in both groups. Fungal loads were not measured in the study. The adverse event profile in the steroid group was markedly higher versus the itraconazole treatment [10].

The antifungal treatment benefit in ABPA may not be restricted to itraconazole - in a retrospective study of patients with ABPA and SAFS, clinical response to voriconazole was observed in $12 / 16(75 \%)$ and in $7 / 9(78 \%)$ for posaconazole [13]. Further evidence for the benefit of antifungal intervention in ABPA has been evidenced by positive therapeutic benefit with the use of inhaled amphotericin [11, 12, 60]. In a recent prospective study of 21 ABPA patients, authors compared treatment with nebulised amphotericin and budesonide versus budesonide alone [12]. While the study was insufficiently powered to detect differences in immune biomarkers, the number of patients experiencing exacerbations was significantly lower in the antifungal arm compared to the budesonide arm (1/12 [8.3\%] vs. $6 / 9$ [66.7\%]. The study did not report measurement of fungal load in sputum. A number of retrospective studies have highlighted the high incidence of bronchospasm with inhaled amphotericin which restricts widespread utility in this population $[11,60]$.

Only two prospective, double blind controlled clinical trials of antifungal therapy in patients with SAFS have been published. An early trial of 8 months of itraconazole (FAST study) reported improvement in quality of life scores [61] and pulmonary function tests whilst a subsequent 3 month study (EVITA3) found that voriconazole was not effective [62].

In the FAST study, fifty-eight patients with severe asthma (BTS level 4 or 5) and receiving high dose inhaled 
steroids were enrolled and treated with itraconazole $200 \mathrm{mg}$ BD or placebo. Patient inclusion was based on positive RAST and skin prick testing to Aspergillus fumigatus, Cladosporium, Penicillium spp, Candida albicans, Trichophyton spp., Alternaria and Botrytis cinerea. The primary end point in the FAST study was change in the Asthma Quality of Life Questionnaire (AQLQ) score. At 32 weeks, significant improvements were reported in AQLQ score, rhinitis scores, peak expiratory flow rates and total serum IgE in the itraconazole treatment group. The 25 itraconazole subjects who received at least 4 weeks of treatment had individual plasma itraconazole concentrations ranging from 0.65 to $26.1 \mathrm{mg} / \mathrm{L}$ with a median of $8.9 \mathrm{mg} / \mathrm{L}$. Reversion to pre-treatment status occurred within 4 months following discontinuation of itraconazole therapy [61].

High rates of Aspergillus colonisation were documented in the EVITA3 study in which $81 \%$ of subjects in the placebo group and $84 \%$ of subjects in the voriconazole group had at least one positive sputum culture for A. fumigatus. However, culture conversion only occurred in 12 patients in the voriconazole treatment group-the remainder were classified possible responses $(n=5)$ or treatment failures $(n=7)$ [62]. Unlike the FAST study, no reduction in total IgE levels were observed, but the duration of therapy was only 3 months. This is in contrast to studies with itraconazole where reductions in total IgE have been observed (Table 2).

Voriconazole levels were measured in 24 patients taking placebo and 26 patients taking voriconazole. Sub-therapeutic voriconazole levels (mean level 0.89 $[0.2-2.8 \mu \mathrm{g} / \mathrm{ml}$ ) were found in a number of patients. The lack of consistent antifungal efficacy may be due to factors including non-linear pharmacokinetics which causes greater inter-individual variability in voriconazole steadystate levels when compared with itraconazole. Itraconazole has greater lipophilicity than voriconazole which results in a greater volume of distribution and this results in a higher plasma: lung ratio than voriconazole $[63,64]$.

Inhibition by hepatic CYP3A4 by itraconazole may result in increased levels of corticosteroids including budesonide and fluticasone [9, 65-67]. A sub-group of 27 patients in the FAST study was evaluated to address this interaction. Reduced plasma cortisol $(<50 \mathrm{nmol} / \mathrm{L})$ was observed in six of 13 itraconazole-treated patients but not seen in the placebo treated subjects. There was no evidence that patients with the corticosteroid interaction exhibited a greater improvement in asthma symptom scores than those who did not, but numbers were too low to offer conclusive evidence [61].

Therapeutic intervention with antifungal agents has been studied in other populations which include chronic fungal infection of the skin and nails with fungal sensitisation linked with asthma. A small prospective double blind, placebo-controlled study recruited 11 patients with severe asthma, dermatophyte infection (onychomycosis and tinea pedis) and sensitisation with Trichophyton [68]. Patients were randomized to treatment with oral fluconazole $100 \mathrm{mg}$ daily or placebo for 5 months followed by open label treatment for an additional 5 months in all patients. At study inclusion, all patients had positive immediate skin test responses to Trichophyton extract, 9 patients had serum IgE antibodies to $T$. tonsurans, antigen specific IgE antibodies were detected in 8 patients and all patients had measurable IgG and $\operatorname{IgG}_{4}$ levels. Sinus CT scans documented extensive disease in 8 patients (4 patients had previously had sinus surgery) reflecting extensive allergic disease. Antifungal treatment was associated with marked improved in asthma symptoms, reduced requirement for corticosteroids and increased peak expiratory flow rates in 9 of 11 patients at the end of the study period. Improvements in asthma control paralleled progressive decrease in signs of fungal infection in the skin and nails suggesting that a reduction in fungal burden accounted for the therapeutic benefit. The response in this study was consistent with previously documented improvements in a similar population treated with griseofulvin [69].

A recent prospective clinical study adopted a new approach [70]. Patients with severe asthma were randomised either to treatment for 4 months with oral itraconazole $(n=50)$ or to oral prednisolone for 1 month $(n=50)$ without prior testing for the presence of fungi or markers of fungal sensitisation. Treatment was well tolerated in both groups. Improvements in asthma control (ACT scores), lung function and symptoms were significantly greater in the itraconazole group at 1 month versus the oral prednisolone treatment group. The therapeutic benefit for azole treatment was maintained for the 4 months treatment period. Treatment with itraconazole had no effect on IgE nor on eosinophils leading the authors to conclude that the observed antifungal treatment benefit is most likely to result from reductions in airway fungal burden.

\section{Proposed treatment algorithm for the asthmatic patient with fungal sensitisation (SAFS)}

We propose here a treatment algorithm for patients with severe asthma, but first address several key decision points in management (Fig. 3).

- Should SAFS be treated with antifungals in absence of fungal colonisation of the airways?

The therapeutic benefits for antifungal intervention in SAFS assume that elimination of fungal replication in the 


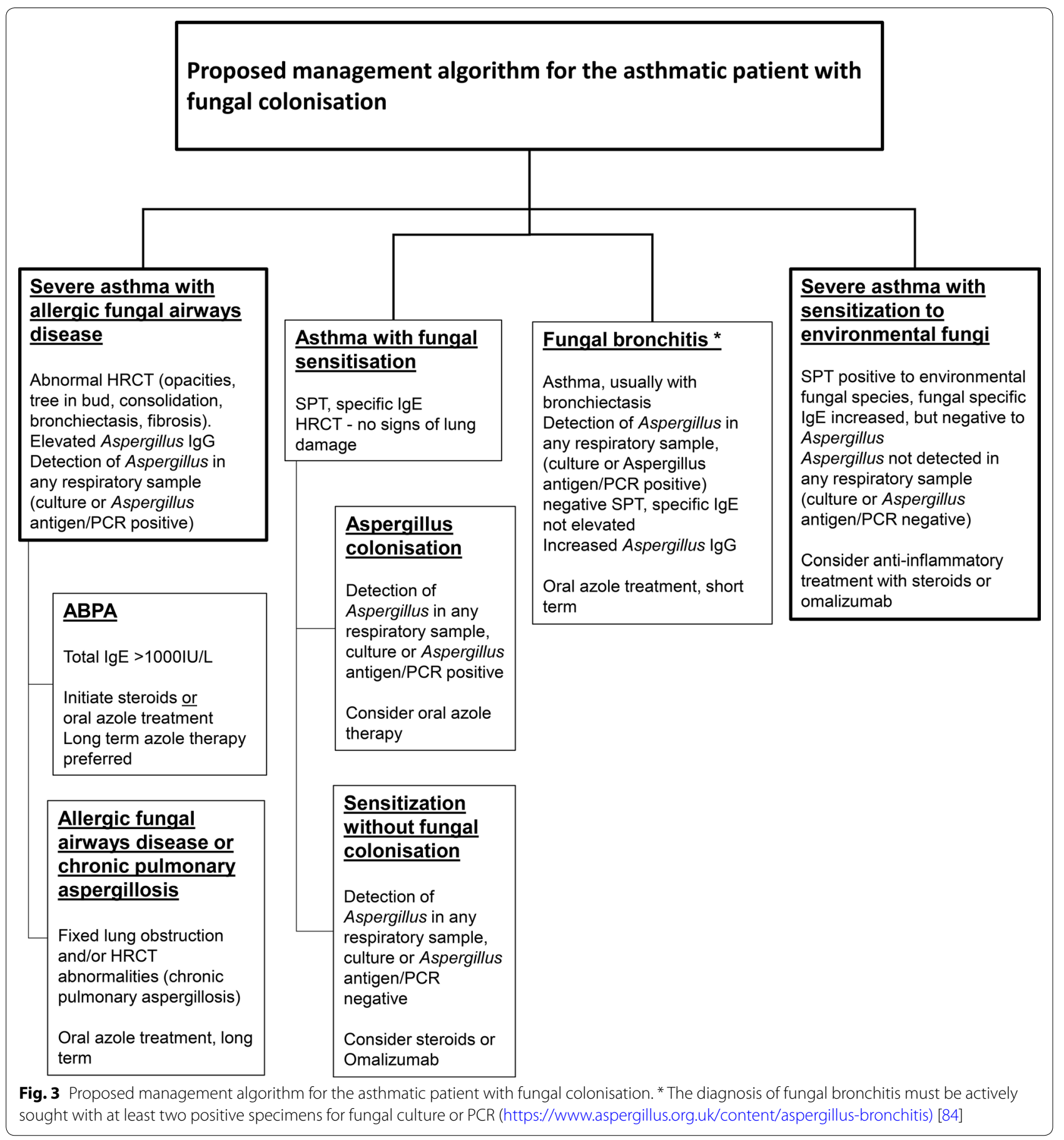

airways may reduce antigenic stimulus which therefore results in therapeutic improvement. As discussed above, evidence in favour of antifungal therapy has been highlighted in a small number of prospective controlled trials in ABPA and SAFS but none of these have required fungal colonisation as a basis for study entry nor have they studied fungal burden using serial testing $[10,58,59,61]$.
The question is complicated by the insensitivity of standard culture methods for detection of colonisation in sputum samples. Routine clinical laboratory methods using sputum samples (e.g. using the HPA method) report positive detection in only $10 \%$ of samples [35]. Using customized separation or high-volume methods, significantly higher rates of $A$. fumigatus have been 
detected in sputum samples from sensitised asthmatics, but these assays are not routinely available [35]. PCR assays are sensitive and offer semi-quantitative data but only provide indirect evidence for fungal replication. It is also recognised that the fungal burden in ABPA and severe asthma is highly variable within and between individuals $[8,35,37,56]$. Due to high sample and yield variability, serial testing for fungal colonisation is recommended in the asthmatic with sensitisation to thermotolerant species.

Based on the lack of evidence, it is not possible to recommend antifungal treatment for sensitised asthmatics who have no evidence of fungal colonisation based on at least 3 specimens submitted for fungal culture or Aspergillus PCR. The one exception may be patients with concomitant cutaneous dermatophyte infection, but the treatment should be directed at the skin infection.

- Is antifungal therapy justified in severe asthmatics with fungal specific sensitisation, fungal colonisation, fixed lung obstruction and/or the presence of radiological abnormalities?

There is increasing consensus that ABPA and SAFS are overlapping conditions which argues for a pragmatic definition which ignores the requirement for total IgE levels greater than $1000 \mathrm{IU} / \mathrm{L}[4,6,39,40]$. Although systemic steroids are highly efficacious in the management of ABPA, almost $50 \%$ of patients relapse when they are tapered and $20-45 \%$ become glucocorticoid dependent (currently in India) or become reliant on high dose inhaled steroids $[6,71]$. In addition, high dose steroids are associated with a much higher rate of adverse events which argues for the use of antifungals as first choice therapy for long term asthma and ABPA control in this population [10].

The case for antifungal therapy in patients with ABPA is strongly supported by a number of studies $[10,58,59$, 72, 73]. Benefits of antifungals for ABPA and SAFS have identified major steroid reductions and improvement in asthma control as the most important [5].

Given the increasing consensus regarding the overlap of ABPA and severe asthma, fungal sensitisation and radiological features of lung damage, it seems likely that antifungal therapy would offer significant therapeutic benefit to the majority of patients who meet some of the criteria for ABPA irrespective of total IgE levels $[4,6$, $39,40]$. The rationale for antifungal therapy is strengthened by evidence for airways colonisation. It should also be noted that existing data supports a pathogenic role for Aspergillus in severe asthma, but this has not been established for thermotolerant yeasts such as Candida albicans which are frequently encountered colonizing the airways [39, 40].

It is evident that there is high unmet clinical need for improved antifungal therapies for the asthmatic with greater efficacy, safety, tolerability and avoidance of drug interactions (particularly glucocorticoids). The use of inhaled antifungals which enable sustained pulmonary drug concentrations to the site of endobronchial colonisation offers an attractive alternative to the use oral antifungals whilst avoiding the risk of systemic toxicities and adverse drug interactions. The emergence of resistance with the use of oral antifungals is a significant concern and the use of inhaled therapies with maintenance of high local drug concentrations would be expected to reduce this risk.

Four inhaled antifungals are currently in development for the treatment of fungal infections in ABPA and severe asthma or invasive aspergillosis. PUR1900 (Pulmatrix Inc) is a novel dry powder formulation of Itraconazole which has been repurposed for the treatment of adult asthmatics with ABPA [74, 75]. ZP-059 (Zambon Company S.P.A.) and TFF-VORI (TFF pharmaceuticals) are inhaled forms of voriconazole, and both completed phase 1 recently [76, 77]. PC945 is a novel azole compound which has been designed for topical administration, demonstrating a long duration of action and is being studied in asthmatics (ClinicalTrials.gov Identifier: NCT03745196) [78, 79]. Recently, FDA organized a workshop entitled "Addressing Challenges in Inhaled Antifungal Drug Development", to discuss the challenges and clinical trial design considerations for developing inhaled antifungal drugs [80].

\section{Economics of severe asthma}

Severe asthma is expensive for patients in terms of time off work and inability to fulfil other social responsibilities and for healthcare systems [81]. In the US, sources claim that the relative minority of severe exacerbators account for a disproportionate degree of total direct treatment costs $(>80 \%)$, driven by the expense of emergency department or hospital treatment. Patients who have exacerbations face high healthcare costs, with one commentator suggesting that a single exacerbation requiring additional pharmacotherapy (or more aggressive intervention) can more than triple annual treatment costs [44].

This high expense has allowed the development of multiple novel therapies for severe asthma, mostly targeting individual components of the allergic immune cascade and delivered as monoclonal antibodies (see Table 3product, target, year of licensure). While the economics of these new treatments puts some strain on healthcare systems in high income countries, the return in terms of reduced unscheduled care needs, less time off work and 
Table 3 Asthma pricing-biologics

\begin{tabular}{|c|c|c|c|c|c|c|}
\hline \multirow[t]{2}{*}{ Product } & \multirow[t]{2}{*}{ Company } & \multirow[t]{2}{*}{ Target } & \multirow{2}{*}{$\begin{array}{l}\text { Year of market } \\
\text { licensing }\end{array}$} & \multicolumn{3}{|c|}{ Price of 6 months treatment } \\
\hline & & & & USA (USD) & UK (USD) & France (USD) \\
\hline Xolair (omalizumab) & Roche/Novartis & $\lg E$ & 2003 & $21.2 \mathrm{~K}$ & $17.4 \mathrm{k}$ & $20.5 \mathrm{~K}$ \\
\hline Nucala (mepolizumab) & GSK & $\mathrm{IL}-5$ & 2015 & $19.2 \mathrm{~K}$ & $7.2 \mathrm{~K}$ & $7.3 \mathrm{~K}$ \\
\hline Cinqair/Cinqaero (reslizumab) & Teva & $\mathrm{IL}-5$ & 2016 & $17.4 \mathrm{~K}$ & $8.4 \mathrm{~K}$ & $\mathrm{n} / \mathrm{a}$ \\
\hline Fasenra (benralizumab) & AstraZeneca / Kyowa Hakko Kirin & IL-5R & 2017 & $19.2 \mathrm{~K}$ & $16.6 \mathrm{~K}$ & $14.4 \mathrm{~K}$ \\
\hline Dupixent (dupilumab) & Sanofi-Genzyme Regeneron & $\begin{array}{l}\mathrm{IL}-4 \\
\mathrm{IL}-13\end{array}$ & 2018 & $21.1 \mathrm{~K}$ & $10.8 \mathrm{~K}$ & $10.4 \mathrm{~K}$ \\
\hline
\end{tabular}

n/a, not applicable

Sources: RedBook Online, accessed Jan 2020 [94]; MIMS Online, accessed Jan 2020 [95]; Akuthota and Weller UpToDate, 2018 [96]

Note: The US price is the wholesale acquisition cost (WAC), which is the manufacturer's list price for a product when sold to wholesalers. The WAC may not represent actual transaction prices and does not include discounts or rebates Assumptions: Exchange rate of $£ 1: \$ 1.30, € 1: \$ 1.20$

US Prescribing Information and European SPCs; RedBook Online, accessed Feb 2019 [94]; MIMS Online, accessed Feb 2019 [95]

Xolair dose depends on body weight and pre-treatment IgE serum levels. The US price is the wholesale acquisition cost (WAC), which is the manufacturer's list price for a product when sold to wholesalers. The WAC may not represent actual transaction prices and does not include discounts or rebates Assumptions: (1) average body weight of $75 \mathrm{~kg}$; (2) no sharing of vials between patients; (3) exchange rate of $£ 1: \$ 1.29$, XE, com, Feb 2019

Table 4 US and UK Pricing of Itraconazole

\begin{tabular}{lllll}
\hline Generic name & Brand name & $\begin{array}{l}\text { Assumed } \\
\text { dosing regimen }\end{array}$ & \multicolumn{2}{l}{$\begin{array}{l}\text { Cost of } 6 \text { months } \\
\text { treatment }\end{array}$} \\
\cline { 3 - 5 } & & US (USD) & UK (USD) \\
\hline Itraconazole & Generic & 200 mg twice- & 5418 & 198 \\
& Sporanox & daily & 20,547 & 869 \\
\hline
\end{tabular}

Sources: RedBook Online, accessed Jan 2020 [94]; MIMS Online, accessed Jan 2020 [95], Akuthota and Weller 2018 [96]

The US price is the wholesale acquisition cost (WAC), which is the manufacturer's list price for a product when sold to wholesalers. The WAC may not represent actual transaction prices and does not include discounts or rebates. Assumption: Exchange rate of $£ 1: \$ 1.30 \mathrm{ab}$

social benefit in terms of improved health are affordable. The same is not true for low- and middle-income countries, where such costs are prohibitive, especially as long-term therapy is required. The conventional model for such expensive products is to wait until they are off patent and less expensive generics become more affordable, at least in middle income countries. With monoclonal therapies, the production and delivery cost of generic biosimilars will not realise such major reductions in price for low resource settings, and only small molecule development targeting the same pathways as the monoclonal agents is likely to (eventually) be affordable.

In contrast, oral antifungal therapy is available in most countries and is relatively inexpensive compared to biologicals (Table 4). Both itraconazole and voriconazole are listed on the WHO's Essential Medicines List [82]. For example, 6 months' treatment cost of oral itraconazole (at $400 \mathrm{mg}$ daily) is $\$ 86.4$ in Peru, $\$ 180$ in Thailand, \$136.8 in Egypt, \$138.6 in Uganda, \$153 in Ghana, \$243 in Cote d'Ivoire to name a few low price examples [83]. If a mean daily price of under $\$ 1.00$ for itraconazole could be established in all low and low middle-income countries, then the annual cost (not including local pharmacy dispensing fees which can be very high) would provide therapy at under $\$ 400$. While this is still too much for most people in the very poorest countries, it is affordable for several billion people.

\section{Conclusions}

Severe asthma is characterised by difficult to control disease with long-term declines in lung function, irreversible airways remodelling, impaired quality of life and increased risk for life-threatening exacerbations with attendant health cost implications. Amongst the recognised associations with severe asthma, two overlapping syndromes which result from sensitisation to Aspergillus and other airborne fungi (ABPA and SAFS). Evidence suggests that persistent non-invasive endobronchial fungal colonisation with Aspergillus in severe asthma is directly associated with signs of lung damage (including bronchiectasis, multiple lung opacities, lung fibrosis). Positive therapeutic benefit has been reported with oral antifungal treatment in a number of prospective studies in ABPA. However, there is a paucity of therapeutic of data supporting therapeutic intervention in SAFS and further studies are required to address this question. Currently, the risk benefit relationship for antifungal therapy must be balanced by the need for prolonged therapy, systemic adverse effects, liability to drug interactions and concern over the emergence of resistance. The recognition that the persistent presence of Aspergillus in the respiratory tract is associated with adverse outcomes enables the targeting of the sub-population most likely to benefit from antifungal treatment. 


\section{Supplementary information}

Supplementary information accompanies this paper at https://doi. org/10.1186/s13601-020-00353-8.

Additional file 1: Table S1. Fungal nomenclature for common allergenic fungi.

\section{Abbreviations}

ABPA: Allergic bronchopulmonary aspergillosis; ABPM: Allergic bronchopulmonary mycosis; CF: Cystic fibrosis; DB: Double blind; HAM: High attenuation mucous; PC: Placebo control; PCR: Polymerase chain reaction; RAST: Radio allegro-sorbent test; SAFS: Severe asthma with fungal sensitisation; SPT: Skin prick tests.

\section{Acknowledgements}

Mr Mark Brimble of Globe Life Sciences for his assistance on the economics of asthma.

\section{Authors' contributions}

GR and DD equally contributed to the preparation of original draft manuscript and revised version. KI contributed to creation of tables and critical review/ editing of the manuscript. All authors read and approved the final manuscript.

\section{Funding}

Publication cost is funded by Pulmocide Ltd.

\section{Availability of data and materials}

Not applicable.

\section{Ethics approval and consent to participate}

Not applicable.

\section{Consent for publication}

Not applicable.

\section{Competing interests}

Dr. Rapeport is a co-founder, former employee and shareholder in Pulmocide Ltd. Dr. Ito is a current employee and holds share options in Pulmocide Ltd. Dr. Denning and family hold Founder shares in F2G Ltd, a University of Manchester spin-out antifungal discovery company. He acts or has recently acted as a consultant to Scynexis, Pulmatrix, Pulmocide, Zambon, iCo Therapeutics, Mayne Pharma, Roivant, Biosergen, Bright Angel Therapeutics and Fujifilm. In the last 3 years, he has been paid for talks on behalf of Dynamiker, Hikma, Gilead, Merck, Mylan and Pfizer. He is a longstanding member of the Infectious Disease Society of America Aspergillosis Guidelines group, the European Society for Clinical Microbiology and Infectious Diseases Aspergillosis Guidelines group.

\section{Author details}

${ }^{1}$ Airways Disease, National Heart and Lung Institute, Imperial College, London SW3 6LY, UK. ${ }^{2}$ Pulmocide Ltd., 44 Southampton Building, London WC2A 1AP, UK. ${ }^{3}$ Manchester Fungal Infection Group (MFIG), Faculty of Biology, Medicine and Health, The University of Manchester, Manchester Academic Health Science Centre, Manchester M13 9PL, UK

Received: 27 April 2020 Accepted: 19 October 2020

Published online: 06 November 2020

\section{References}

1. Chung KF, Wenzel SE, Brozek JL, Bush A, Castro M, Sterk PJ, et al. International ERS/ATS guidelines on definition, evaluation and treatment of severe asthma. Eur Respir J. 2014;43(2):343-73.

2. Lotvall J, Akdis CA, Bacharier LB, Bjermer L, Casale TB, Custovic A, et al. Asthma endotypes: a new approach to classification of disease entities within the asthma syndrome. J Allergy Clin Immunol. 2011;127(2):355-60.
3. Denning DW, O'Driscoll BR, Hogaboam CM, Bowyer P, Niven RM. The link between fungi and severe asthma: a summary of the evidence. Eur Respir J. 2006;27(3):615-26.

4. Baxter CG, Dunn G, Jones AM, Webb K, Gore R, Richardson MD, et al. Novel immunologic classification of aspergillosis in adult cystic fibrosis. J Allergy Clin Immunol. 2013;132(3):560-6.

5. Denning DW, Pashley C, Hartl D, Wardlaw A, Godet C, Del Giacco S, et al. Fungal allergy in asthma-state of the art and research needs. Clin Transl Allergy. 2014;4:14

6. Agarwal R, Chakrabarti A, Shah A, Gupta D, Meis JF, Guleria R, et al. Allergic bronchopulmonary aspergillosis: review of literature and proposal of new diagnostic and classification criteria. Clin Exp Allergy. 2013:43(8):850-73.

7. Woolnough KF, Richardson M, Newby C, Craner M, Bourne M, Monteiro $W$, et al. The relationship between biomarkers of fungal allergy and lung damage in asthma. Clin Exp Allergy. 2017:47(1):48-56.

8. Farrant J, Brice H, Fowler S, Niven R. Fungal sensitisation in severe asthma is associated with the identification of Aspergillus fumigatus in sputum. J Asthma. 2016;53(7):732-5.

9. Menzies D, Holmes L, McCumesky G, Prys-Picard C, Niven R. Aspergillus sensitization is associated with airflow limitation and bronchiectasis in severe asthma. Allergy. 2011;66(5):679-85.

10. Agarwal R, Dhooria S, Singh Sehgal I, Aggarwal AN, Garg M, Saikia B, et al. A randomized trial of itraconazole vs prednisolone in acute-stage allergic bronchopulmonary aspergillosis complicating asthma. Chest. 2018;153(3):656-64.

11. Chishimba L, Langridge P, Powell G, Niven RM, Denning DW. Efficacy and safety of nebulised amphotericin $B(N A B)$ in severe asthma with fungal sensitisation (SAFS) and allergic bronchopulmonary aspergillosis (ABPA). J Asthma. 2015;52(3):289-95.

12. Ram B, Aggarwal AN, Dhooria S, Sehgal IS, Garg M, Behera D, et al. A pilot randomized trial of nebulized amphotericin in patients with allergic bronchopulmonary aspergillosis. J Asthma. 2016;53(5):517-24.

13. Chishimba L, Niven RM, Cooley J, Denning DW. Voriconazole and posaconazole improve asthma severity in allergic bronchopulmonary aspergillosis and severe asthma with fungal sensitization. J Asthma. 2012;49(4):423-33.

14. Quansah R, Jaakkola MS, Hugg TT, Heikkinen SA, Jaakkola JJ. Residentia dampness and molds and the risk of developing asthma: a systematic review and meta-analysis. PLoS ONE. 2012;7(11):e47526.

15. Reponen T, Lockey J, Bernstein DI, Vesper SJ, Levin L, Khurana Hershey GK, et al. Infant origins of childhood asthma associated with specific molds. J Allergy Clin Immunol. 2012;130(3):639-44.

16. Norback D, Zock JP, Plana E, Heinrich J, Svanes C, Sunyer J, et al. Mould and dampness in dwelling places, and onset of asthma: the population-based cohort ECRHS. Occup Environ Med. 2013;70(5):325-31.

17. Newson R, Strachan D, Corden J, Millington W. Fungal and other spore counts as predictors of admissions for asthma in the Trent region. Occup Environ Med. 2000;57(11):786-92.

18. Atkinson RW, Strachan DP, Anderson HR, Hajat S, Emberlin J. Temporal associations between daily counts of fungal spores and asthma exacerbations. Occup Environ Med. 2006;63(9):580-90.

19. Stern DA, Morgan WJ, Halonen M, Wright AL, Martinez FD. Wheezing and bronchial hyper-responsiveness in early childhood as predictors of newly diagnosed asthma in early adulthood: a longitudinal birthcohort study. Lancet. 2008;372(9643):1058-64.

20. Backman H, Jansson SA, Stridsman C, Eriksson B, Hedman L, Eklund BM, et al. Severe asthma - a population study perspective. Clin Exp Allergy. 2019;49(6):819-28.

21. von Bulow A, Kriegbaum M, Backer V, Porsbjerg C. The prevalence of severe asthma and low asthma control among Danish adults. J Allergy Clin Immunol Pract. 2014;2(6):759-67.

22. Hekking PP, Wener RR, Amelink M, Zwinderman AH, Bouvy ML, Bel EH. The prevalence of severe refractory asthma. J Allergy Clin Immunol. 2015;135(4):896-902.

23. Varsano S, Segev D, Shitrit D. Severe and non-severe asthma in the community: A large electronic database analysis. Respir Med. 2017:123:131-9.

24. Jaakkola MS, leromnimon A, Jaakkola JJ. Are atopy and specific IgE to mites and molds important for adult asthma? J Allergy Clin Immunol. 2006:117(3):642-8. 
25. Siroux V Boudier A, Bousquet J, Bresson IL Cracowski لL, Ferran J, et al. Phenotypic determinants of uncontrolled asthma. J Allergy Clin Immunol. 2009:124(4):681-7.

26. O'Driscoll BR, Powell G, Chew F, Niven RM, Miles JF, Vyas A, et al. Comparison of skin prick tests with specific serum immunoglobulin $E$ in the diagnosis of fungal sensitization in patients with severe asthma. Clin Exp Allergy. 2009;39(11):1677-83.

27. O'Driscoll BR, Hopkinson LC, Denning DW. Mold sensitization is common amongst patients with severe asthma requiring multiple hospital admissions. BMC Pulm Med. 2005;5:4.

28. Goh KJ, Yii ACA, Lapperre TS, Chan AK, Chew FT, Chotirmall SH, et al. Sensitization to Aspergillus species is associated with frequent exacerbations in severe asthma. J Asthma Allergy. 2017;10:131-40.

29. Denning DW, Pleuvry A, Cole DC. Global burden of chronic pulmonary aspergillosis complicating sarcoidosis. Eur Respir J. 2013;41(3):621-6.

30. Kwizera R, Musaazi J, Meya DB, Worodria W, Bwanga F, Kajumbula H, et al. Burden of fungal asthma in Africa: a systematic review and meta-analysis. PLoS ONE. 2019;14(5):e0216568.

31. Agarwal R, Denning DW, Chakrabarti A. Estimation of the burden of chronic and allergic pulmonary aspergillosis in India. PLOS ONE. 2014;9(12):e114745

32. Giacomazzi J, Baethgen L, Carneiro LC, Millington MA, Denning DW, Colombo AL, et al. The burden of serious human fungal infections in Brazil. Mycoses. 2016;59(3):145-50.

33. GAFFl, editor Burden of serious fungal disease in Latin America, by country and disease. Global Fungal Infection Forum 4 in Lima; 2019.

34. Fairs A, Agbetile J, Hargadon B, Bourne M, Monteiro WR, Brightling CE, et al. IgE sensitization to Aspergillus fumigatus is associated with reduced lung function in asthma. Am J Respir Crit Care Med. 2010;182(11):1362-8.

35. Pashley CH, Fairs A, Morley JP, Tailor S, Agbetile J, Bafadhel M, et al. Routine processing procedures for isolating filamentous fungi from respiratory sputum samples may underestimate fungal prevalence. Med Mycol. 2012;50(4):433-8.

36. Ghebre MA, Desai D, Singapuri A, Woods J, Rapley L, Cohen S, et al. Sputum inflammatory mediators are increased in Aspergillus fumigatus culture-positive asthmatics. Allergy Asthma Immunol Res. 2017;9(2):177-81.

37. Agbetile J, Fairs A, Desai D, Hargadon B, Bourne M, Mutalithas K, et al. Isolation of filamentous fungi from sputum in asthma is associated with reduced post-bronchodilator FEV1. Clin Exp Allergy. 2012;42(5):782-91.

38. Chrdle A, Mustakim S, Bright-Thomas RJ, Baxter CG, Felton T, Denning DW Aspergillus bronchitis without significant immunocompromise. Ann N Y Acad Sci. 2012:1272:73-85.

39. Woolnough K, Fairs A, Pashley CH, Wardlaw AJ. Allergic fungal airway disease: pathophysiologic and diagnostic considerations. Curr Opin Pulm Med. 2015;21(1):39-47.

40. Rick EM, Woolnough K, Pashley CH, Wardlaw AJ. Allergic Fungal Airway Disease. J Investig Allergol Clin Immunol. 2016;26(6):344-54.

41. Li E, Knight JM, Wu Y, Luong A, Rodriguez A, Kheradmand F, et al. Airway mycosis in allergic airway disease. Adv Immunol. 2019;142:85-140.

42. Fukutomi Y, Taniguchi M. Sensitization to fungal allergens: resolved and unresolved issues. Allergol Int. 2015:64(4):321-31.

43. Bowyer P, Fraczek M, Denning DW. Comparative genomics of fungal allergens and epitopes shows widespread distribution of closely related allergen and epitope orthologues. BMC Genomics. 2006;7:251.

44. Canonica GW, Ansotegui IJ, Pawankar R, Schmid-Grendelmeier P, van Hage M, Baena-Cagnani CE, et al. A WAO - ARIA - GA(2)LEN consensus document on molecular-based allergy diagnostics. World Allergy Organ J. 2013:6(1):17.

45. Muthu V, Sehgal IS, Dhooria S, Aggarwal AN, Agarwal R. Utility of recombinant Aspergillus fumigatus antigens in the diagnosis of allergic bronchopulmonary aspergillosis: a systematic review and diagnostic test accuracy meta-analysis. Clin Exp Allergy. 2018;48(9):1107-36.

46. Melioli G, Compalati E, Bonini S, Canonica GW. The added value of allergen microarray technique to the management of poly-sensitized allergic patients. Curr Opin Allergy Clin Immunol. 2012;12(4):434-9.

47. Agarwal R. Severe asthma with fungal sensitization. Curr Allergy Asthma Rep. 2011;11(5):403-13.

48. Harada K, Oguma T, Saito A, Fukutomi Y, Tanaka J, Tomomatsu K, et al. Concordance between Aspergillus-specific precipitating antibody and $\operatorname{lgG}$ in allergic bronchopulmonary aspergillosis. Allergol Int. 2018;67S:S12-7.
49. Baxter CG, Denning DW, Jones AM, Todd A, Moore CB, Richardson MD Performance of two Aspergillus IgG EIA assays compared with the precipitin test in chronic and allergic aspergillosis. Clin Microbiol Infect. 2013;19(4):E197-204.

50. Agarwal R, Dua D, Choudhary H, Aggarwal AN, Sehgal IS, Dhooria S, et al. Role of Aspergillus fumigatus-specific lgG in diagnosis and monitoring treatment response in allergic bronchopulmonary aspergillosis. Mycoses. 2017;60(1):33-9.

51. Asano K, Hebisawa A, Ishiguro T, Takayanagi N, Nakamura Y, Suzuki J, et al. New clinical diagnostic criteria for allergic bronchopulmonary aspergillosis/mycosis and its validation. J Allergy Clin Immunol. 2020;12:36.

52. Stucky Hunter E, Richardson MD, Denning DW. Evaluation of LDBio Aspergillus ICT lateral flow assay for IgG and IgM antibody detection in chronic pulmonary aspergillosis. J Clin Microbiol. 2019;57:9.

53. Stucky Hunter E, Richardson M, Denning DW. Evaluation of the LDBio Aspergillus ICT lateral flow assay for serodiagnosis of allergic bronchopulmonary aspergillosis. PloS one. 2020;39:223.

54. Van Hoeyveld E, Dupont L, Bossuyt X. Quantification of lgG antibodies to Aspergillus fumigatus and pigeon antigens by ImmunoCAP technology: an alternative to the precipitation technique? Clin Chem. 2006;52(9):1785-93.

55. Sullivan A, Hunt EB, Ward C, Lapthorne S, Eustace JA, Fanning LJ, et al. The presence of Aspergillus fumigatus in asthmatic airways is not clearly related to clinical disease severity. Allergy. 2020;75(5):1146-54.

56. Fraczek MG, Chishimba L, Niven RM, Bromley M, Simpson A, Smyth L, et al. Corticosteroid treatment is associated with increased filamentous fungal burden in allergic fungal disease. J Allergy Clin Immunol. 2018;142(2):407-14

57. Rick EM, Woolnough KF, Seear PJ, Fairs A, Satchwell J, Richardson M, et al. The airway fungal microbiome in asthma. Clin Exp Allergy. 2020;9:8-18.

58. Stevens DA, Schwartz HJ, Lee JY, Moskovitz BL, Jerome DC, Catanzaro A et al. A randomized trial of itraconazole in allergic bronchopulmonary aspergillosis. N Engl J Med. 2000;342(11):756-62.

59. Wark PA, Hensley MJ, Saltos N, Boyle MJ, Toneguzzi RC, Epid GD, et al. Anti-inflammatory effect of itraconazole in stable allergic bronchopulmonary aspergillosis: a randomized controlled trial. J Allergy Clin Immunol. 2003;111(5):952-7.

60. Otu AA, Langridge P, Denning DW. An evaluation of nebulised amphotericin B deoxycholate (Fungizone((R)) ) for treatment of pulmonary aspergillosis in the UK National Aspergillosis Centre. Mycoses. 2019;62(11):1049-55.

61. Denning DW, O'Driscoll BR, Powell G, Chew F, Atherton GT, Vyas A, et al. Randomized controlled trial of oral antifungal treatment for severe asthma with fungal sensitization: the Fungal Asthma Sensitization Trial (FAST) study. Am J Respir Crit Care Med. 2009;179(1):11-8.

62. Agbetile J, Bourne M, Fairs A, Hargadon B, Desai D, Broad C, et al. Effectiveness of voriconazole in the treatment of Aspergillus fumigatus-associated asthma (EVITA3 study). J Allergy Clin Immunol. 2014;134(1):33-9.

63. Felton T, Troke PF, Hope WW. Tissue penetration of antifungal agents. Clin Microbiol Rev. 2014;27(1):68-88.

64. Coronel B, Levron JC, Dorez D, Van Devenne A, Archimbaud E, Mercatello A. Itraconazole lung concentrations in haematological patients. Mycoses. 2000:43(3-4):125-7.

65. Zhang J, Liu Y, Nie X, Yu Y, Gu J, Zhao L. Trough concentration of itraconazole and its relationship with efficacy and safety: a systematic review and meta-analysis. Infect Drug Resist. 2018;11:1283-97.

66. Raaska K, Niemi M, Neuvonen M, Neuvonen PJ, Kivisto KT. Plasma concentrations of inhaled budesonide and its effects on plasma cortisol are increased by the cytochrome P4503A4 inhibitor itraconazole. Clin Pharmacol Ther. 2002;72(4):362-9.

67. Parmar JS, Howell T, Kelly J, Bilton D. Profound adrenal suppression secondary to treatment with low dose inhaled steroids and itraconazole in allergic bronchopulmonary aspergillosis in cystic fibrosis. Thorax. 2002;57(8):749-50.

68. Ward GW Jr, Woodfolk JA, Hayden ML, Jackson S, Platts-Mills TA. Treatment of late-onset asthma with fluconazole. J Allergy Clin Immunol. 1999;104(3 Pt 1):541-6.

69. Ward GW Jr, Karlsson G, Rose G, Platts-Mills TA. Trichophyton asthma: sensitisation of bronchi and upper airways to dermatophyte antigen. Lancet. 1989;1(8643):859-62. 
70. Mirsadraee M, Dehghan S, Ghaffari S, Mirsadraee N. Long-term effect of antifungal therapy for the treatment of severe resistant asthma: an active comparator clinical trial. Curr Med Mycol. 2019;5(4):1-7.

71. Agarwal R, Gupta D, Aggarwal AN, Behera D, Jindal SK. Allergic bronchopulmonary aspergillosis: lessons from 126 patients attending a chest clinic in north India. Chest. 2006;130(2):442-8.

72. Moreira AS, Silva D, Ferreira AR, Delgado L. Antifungal treatment in allergic bronchopulmonary aspergillosis with and without cystic fibrosis: a systematic review. Clin Exp Allergy. 2014;44(10):1210-27.

73. Elphick HE, Southern KW. Antifungal therapies for allergic bronchopulmonary aspergillosis in people with cystic fibrosis. Cochrane Database Syst Rev. 2016;11:2204.

74. ClinicalTrialsgov. Study in Adult Asthmatic Patients With Allergic Bronchopulmonary Aspergillosis, NCT03960606 https://clinicaltrials.gov/ ct2/show/NCT039606062019. https://clinicaltrials.gov/ct2/show/NCT03 960606.

75. Hava DL, Tan L, Johnson P, Curran AK, Perry J, Kramer S, et al. A phase 1/1b study of PUR1900, an inhaled formulation of itraconazole, in healthy volunteers and asthmatics to study safety, tolerability and pharmacokinetics. Br J Clin Pharmacol. 2020:86(4):723-33.

76. ClinicalTiralsgov. Phase 1 Three Part SAD, MAD \& Cross-Over Study of ZP-059 in Healthy and Asthmatic Subjects, NCT04229303 2020. https:// clinicaltrials.gov/ct2/show/NCT04229303.

77. TFF Pharmaceuticals Announces Topline Results of Voriconazole Inhalation Powder Phase 1 Clinical Trial [press release]. https://ir.tffpharma.com/ news-releases/news-release-details/tff-pharmaceuticals-announces-topli ne-results-voriconazole2020.

78. ClinicalTiralsgov. The Effect of PC945 on Aspergillus or candida lung infections in patients with asthma or chronic respiratory diseases, NCT03745196 https://clinicaltrials.gov/ct2/show/NCT037451962018. https://clinicaltrials.gov/ct2/show/NCT03745196.

79. Colley T, Alanio A, Kelly SL, Sehra G, Kizawa Y, Warrilow AGS, et al. In Vitro and In Vivo Antifungal Profile of a Novel and Long-Acting Inhaled Azole, PC945, on Aspergillus fumigatus Infection. Antimicrob Agents Chemother. 2017:61(5):e02280-e2316.

80. FDA. Workshop: Addressing Challenges in Inhaled Antifungal Drug Development 2020. https://www.fda.gov/drugs/news-events-human-drugs /addressing-challenges-inhaled-antifungal-drug-development-09252 020-09252020.

81. Kaur BP, Lahewala S, Arora S, Agnihotri K, Panaich SS, Secord E, et al. Asthma: Hospitalization Trends and Predictors of In-Hospital Mortality and Hospitalization Costs in the USA (2001-2010). Int Arch Allergy Immunol. 2015;168(2):71-8.

82. WHO. the $21 \mathrm{st}$ WHO Essential Medicines List (EML) https://www.who.int/ medicines/publications/essentialmedicines/en/2019. https://www.who. int/medicines/publications/essentialmedicines/en/.
83. GAFFI. Antifungal drug maps. 2020. https://www.gaffi.org/antifungal -drug-maps/

84. Prats JAGG, Denning DW. Aspergillus bronchitis https://www.aspergillu s.org.uk/content/aspergillus-bronchitis: Aspergillus \& Aspergillosis Website; 2016. https://www.aspergillus.org.uk/content/aspergillus-bronchitis.

85. Shale DJ, Faux JA, Lane DJ. Trial of ketoconazole in non-invasive pulmonary aspergillosis. Thorax. 1987;42(1):26-31.

86. De Beule K, De Doncker P, Cauwenbergh G, Koster M, Legendre R, Blatchford N, et al. The treatment of aspergillosis and aspergilloma with itraconazole, clinical results of an open international study (1982-1987). Mycoses. 1988;31(9):476-85.

87. Currie DC, Lueck C, Milburn HJ, Harvey C, Longbottom JL, Darbyshire JH, et al. Controlled trial of natamycin in the treatment of allergic bronchopulmonary aspergillosis. Thorax. 1990;45(6):447-50.

88. Denning DW, Van Wye JE, Lewiston NJ, Stevens DA. Adjunctive therapy of allergic bronchopulmonary aspergillosis with itraconazole. Chest. 1991;100(3):813-9.

89. Germaud $\mathrm{P}$, Tuchais E. Allergic bronchopulmonary aspergillosis treated with itraconazole. Chest. 1995;107(3):883.

90. Salez F, Brichet A, Desurmont S, Grosbois JM, Wallaert B, Tonnel AB. Effects of itraconazole therapy in allergic bronchopulmonary aspergillosis. Chest. 1999;116(6):1665-8.

91. Rai SP, Panda BN, Bhargava S. Treatment of Allergic Bronchopulmonary Aspergillosis with Fluconazole and Itraconazole. Med J Armed Forces India. 2004:60(2):128-30.

92. Pasqualotto AC, Powell G, Niven R, Denning DW. The effects of antifungal therapy on severe asthma with fungal sensitization and allergic bronchopulmonary aspergillosis. Respirology. 2009;14(8):1121-7.

93. Agarwal R, Dhooria S, Sehgal IS, Aggarwal AN, Garg M, Saikia B, et al. A randomised trial of voriconazole and prednisolone monotherapy in acute-stage allergic bronchopulmonary aspergillosis complicating asthma. Eur Respir J. 2018;52:3.

94. Committee on Infectious Diseases AAoP, Kimberlin, D.W., Brady, M.T., Jackson, M.A., Long, S.S. Report of the Committee on Infectious Disease, Section 3: Summaries of Infectious Disease 2018.

95. MIMS. Drugs https://www.mims.co.uk/: Haymarket Media Group Ltd. ; 2020.

96. Akuthota P, Weller PF. Treatment of allergic bronchopulmonary aspergillosis https://www.uptodate.com/contents/treatment-of-allergic-bronc hopulmonary-aspergillosis. Wolters Kluwer; 2018.

\section{Publisher's Note}

Springer Nature remains neutral with regard to jurisdictional claims in published maps and institutional affiliations.

Ready to submit your research? Choose BMC and benefit from

- fast, convenient online submission

- thorough peer review by experienced researchers in your field

- rapid publication on acceptance

- support for research data, including large and complex data types

- gold Open Access which fosters wider collaboration and increased citations

- maximum visibility for your research: over $100 \mathrm{M}$ website views per year

At $\mathrm{BMC}$, research is always in progress.

Learn more biomedcentral.com/submissions 